\title{
Chapter 4 \\ Humanitarian NGOs and Global \\ Governance: One, No One and One \\ Hundred Thousand Humanitarian NGOs
}

\subsection{Introduction}

To understand the role that NGOs' representation of Syrian displacement plays in global governance before getting into the visual analysis it is important reflect upon the aspirations of emergency organizations. How do relief agencies intend, perceive and present their role to the public? Are they interested in participating or influencing global governance? Do they consider their role as promoters of universal values or technical agents performing a specific task? Answering these questions is important to unpack their distinctiveness and the different ways in which different NGOs conceive and perform their mission in the international arena. In this sense, it is extremely interesting to look at how relief organizations accommodate their humanitarian role and the humanitarian principles within contexts that are inescapably highly political (e.g., situations of violence, displacement, political contestation or belligerent occupation). Not only do NGOs work within a complex web of political interests, international relations and systems of power, but, for better or worse, their humanitarian and advocacy actions have practical political implications. The investigation of how different organizations negotiate their relationship with politics allows us to better understand where each positions itself within the heated debate around the interrelations of humanitarianism and politics discussed in the first chapter.

Barnett has brilliantly argued there have been various indications that NGOs: "might themselves be helping to reproduce and expand the very world order that they claim to resist (...) Certainly many humanitarian agencies do, worrying that their agendas are serving the interests of powerful states, that they are furthering a liberal world order that advantages some over others, and that they are part of governance structures that place them in positions of power over the very people they claim to want to emancipate" (Barnett 2009, 656). 
Yet, at the same time, he points out, these organizations have also shown ethical agency and some degree of reflexivity about their relationship with systems of power, politics and global governance. NGOs have modified their policies, adapted practices, and tried to develop alternative ethics.

Within each organization, there are many different aspects indicative of the space in which they operate: financial (in)dependence from governments; purely humanitarian versus humanitarian-development mandate; needs-based versus rights-based approaches to humanitarian assistance or the objectives of their advocacy strategies. Identifying the different strategic objectives NGOs prioritize (whether psychosocial support, medical assistance, women empowerment, education, or giving a voice to the powerless, to name but a few), allows us to understand which kind of humanitarian role organizations want to play in relation to people they are assisting and societies in which they intervene.

This chapter introduces the four major transnational NGOs - Save the Children, Oxfam, CARE and MSF - outlining their respective histories, current institutional organization, geographical scope and the origin of their funding. It will also outline the role that each has designed for itself by looking at the extent of their mandate, their vision, how their staff reflect on the complicated relationship of their organizations' humanitarian work with politics and global governance, and the key objectives of their advocacy strategies. Finally, the chapter will present NGO-specific interventions in the emergency response to Syrian displacement, both in terms of humanitarian action and advocacy.

\subsection{Save the Children}

The global organization today known as Save the Children was founded in postWorld War I London by Eglantyne Jebb. She was keen to draw public attention to the suffering of children in Austria-Hungary and Germany, defeated countries enduring an Allied blockade. She established the Save the Children Fund in 1919 and in 1924 drafted a document that was adopted by the League of Nations as the Declaration of the Rights of the Child. During World War II Save the Children, continued its focus on the protection of children. Inspired by Jebb, the first humanitarian to use sophisticated fund-raising techniques, local national branches were founded. In 1977, they came together to form an alliance. Today SCF is comprised of 30 national member organisations and a Save the Children International secretariat. Save the Children works in some 120 countries across the globe, primarily engaged in humanitarian relief, health, nutrition, water and sanitation, education, child protection and safeguarding, the rights of the child, advocacy and child poverty.

The website of SCF International and official documents do not explicitly mention humanitarian principles, but they refer to the organization's adherence to the Core Humanitarian Standards (CHS) (CHS 2020)- the essential elements of principled, accountable and high-quality humanitarian action which are based on 
humanitarian principles. Moreover, the organization adheres to Sphere standards for humanitarian action and promotes quality and accountability (Sphere 2020). Save the Children further endorses Code of Conduct for the Red Cross and Red Crescent Movement and NGOs in Disaster Relief (IFRC 1994), which make clear reference to the humanitarian principles.

At the time of the research, Save the Children International and the 30member organizations in 2015 reported a total (annual) gross income of 1.9 billion Euro (Save the Children 2016b). ${ }^{1}$ Nearly two third (58\%) came from institutions, including Governments, the rest from private donations (25\%), corporations and foundations $(13 \%)$, gifts in kind (2\%) and other income sources (2\%) (Save the Children 2016b). The 2016 Global Strategy (Save the Children 2016a) stated among its priorities a desire to "Drive stronger, more diversified funding" so as to raise the percentage of unrestricted funding - funds that are not bound to any specific program and that the agency can use at its own discretion - from $21 \%$ of global income in 2014 to $25 \%$ in 2019, along with increasing the donations from Middle Income Countries. According to Save the Children's Annual Report (Save the Children 2016b), the NGO's expenditures in 2016 amounted to $44 \%$ of the global income for humanitarian programmes and $56 \%$ for development programs.

From a quick look at these data, it emerges quite clearly how from the specific objective to alleviate suffering in a particular historical and geographical context, the organization has grown to have a global presence with global objectives encompassing a very wide range of interventions. With a physical presence in some 120 countries Save the Children is a transnational organization whose scope goes today well beyond the initial goal of feeding hungry children in countries who lost World War I.

\subsubsection{Save the Children and Society}

Although present in several emergency situations around the world, Save the Children's work is not "only" humanitarian: the organization in facts works both on development and humanitarian programmes. Its Global Strategy Ambition for Children 2030 is explicit about it: "millions of children are being left behind and denied the opportunity to survive and fulfil their potential. This document outlines the change we want to inspire by 2030, as well as the strategic steps we will take over the next three years to get there. We will do whatever it takes to ensure by 2030 all children survive, learn and are protected, with a focus on the most deprived and marginalised children" (Save the Children 2016c, 3). While survival and protection mainly refer to the humanitarian objectives of saving lives and alleviating suffering, the objectives referring to children learning and fulfilling their potential have more

\footnotetext{
${ }^{1}$ The official figure is $\$ 2.1$ billion. To make it comparable to the other organization's income in euro, the exchange rate of Inforeuro in December 2016 has been applied.
} 
to do with development work. The idea is to intervene in an comprehensive manner and provide people with 'an integrated response to their needs: immediate humanitarian relief, long-term solutions and continued campaigning for an end to conflicts" (Save the Children 2018e).

Save the Children's holistic approach is reaffirmed in its vision of "a world in which every child attains the right to survival, protection, development and participation' and the organization's mission to 'inspire breakthroughs in the way the world treats children and to achieve immediate and lasting change in their lives" (Save the Children 2018f). Expressions such as change the world, transform lives and building a better world populate the document, and together with the organization's embracing of the rights-based approach (Save the Children 2005), clearly indicate intention to work for long-term goals, well beyond immediate humanitarian assistance. These expressions, however aspirational they may be, can help to understand the role that the NGO conceives for itself in global governance: changing the world and transforming lives. While SCF was established to alleviate the suffering of children today its objectives include a much wider set of actions aimed at improving child rights governance around the world.

Save the Children's goal to affect social and policy changes on children rights (in particular its advocacy for universal ratification of the UN Convention on the Rights of the Child) is presented as a progressive and innovative approach meant to overcome the limitations often associated with traditional, at times considered shortsighted if not unsustainable, humanitarianism. The interaction of humanitarianism with policy reform, and inevitably with its dynamics of power and politics, is considered, and presented, in positive terms, as an important opportunity for Save the Children to have long-term transformative results for on the governance of children rights.

At the same time, and quite oddly, the interrelation of humanitarian work with politics is also considered by the organization as something inherently negative. Even more, avoiding any kind of reference and potential interaction with the political sphere appears more functional for the NGOs' achievement of transformative objectives. In my interviews with Save the Children's staff several informants underlined that the organization did not have anything to do with politics. At the same time, however, all the people I spoke with affirmed that for the NGO performing a role in global governance was extremely important. This widespread opinion was clearly summarized in the words of a Save the Children advocacy and communications manager: "We avoid politics by sticking to the evidence. For example, 50 per cent of Syrian children do not have opportunity to education. If we do not use research, figures, they [national policy makers] will think that we are biased, and we are supportive of refugees. We will instead say that children without education are more prone to be attracted by armed groups, terrorist organizations, drug abuse, etc. We will try to make the policy makers understand that ensuring education for children is in the best interest of Lebanon. We will also say that all support for refugees benefits all of society (not only the refugees). We will not present positions but 
thorough facts that can influence the government position ... We take many factors into account: the donors, the will of the government, needs, and facts." ${ }^{2}$

Despite the irony of an extremely political statement made precisely to avert any implication with politics, it is very interesting to notice how from the NGO perspective politics can be avoided. Implicit in this affirmation, there is also the suggestion that there is a neutral objective reality that NGOs can appeal to in order to remain outside of the political debate. This is a very political a-political statement. ${ }^{3}$ The words of the practitioners indicate that the organization relies on the technicality of its work as something objective and disconnected from the prevalent historical and political environment. Despite the strategic intention of tackling violations of children rights' through a holistic approach taking into consideration the root causes of a given situation, this statement also reveals the assumption that the NGO consider, and present, its role as technical and objective, and that this self-proclaimed a-political stance can be functional in obtaining politically impactful policy and societal transformations.

Within the strategic objective of achieving impact in changing children' lives, advocacy plays a crucial role. As the Save the Children international website states: "for Save the Children, advocacy is the work we do to influence the policies and actions of governments, international institutions and the private sector, in order to achieve positive changes in children's lives (...) In different situations, our advocacy can be focused on securing formal policy changes; driving implementation; or creating an enabling environment for change" (Save the Children 2018a).

Advocacy work is strictly connected with another Save the Children's sector of intervention that the organization itself defines as Child Rights Governance. Under this ambitious title, the NGO works to ensure that governments fulfil children's rights. In practice, this means influencing policy makers to keep children rights at the top of their agenda and promote policies and law changes to ensure that the rights of children are respected. In the organization's words: "In 2014 alone, our work contributed to governments spending more on children in 12 countries, and we helped 18 countries to change policies or laws to make child rights a reality for more children (...) We aim to raise the issue and status of children in all societies to ensure that they are treated as the citizens of today not just tomorrow and in doing so push children and their rights up the political agenda" (Save the Children 2018b).

The crucial role that advocacy plays in the organization's ambition to affect global governance emerges clearly from the fact that the overarching Save the Children's objective to improve child rights governance is primarily based on advocacy and campaigning. Many informants stressed that because of the importance of advocacy within the agency's global strategic objectives, and to ensure capacity to work at different level of governance, each national branch has an advocacy

\footnotetext{
${ }^{2}$ Interview with Save the Children Media Advocacy and Communications Manager, 8th March 2017, Beirut.

${ }^{3}$ I thank Anna Triandafyllidou for this insightful comment.
} 
department at the country level to deal with national issues, and regional and international departments to work respectively at the regional and international level.

Save the Children's advocacy significantly depends on celebrity supporters (described by SCF UK as Artists and Ambassadors). Ilan Kapoor has shown how "celebrities humanitarianism" is intrinsically contaminated and ideological, rather than altruistic. It is problematic not only insofar as its promotes consumerism and corporate capitalism and reifies the north-south inequalities it was intended to address in the first place, but also because it contributes to the depoliticization of global inequalities (Kapoor 2012). The use of celebrities as "Northern saviours" (Van den Bulck 2009; Duvall 2009), most strikingly exemplified by iconic imagery of Princess Diana in the minefields of Angola or Angelina Jolie in the camps of Darfur, is not something new in humanitarian communication. Chouliaraki has noted how celebrity advocacy plays on the level of emotions, by theatrically exposing the celebrities' "authentic" feelings in a way that we can connect with, thereby encouraging "a narcissistic disposition of voyeuristic altruism rather than one of commitment to the humanitarian cause" (Chouliaraki 2012, 17).

In common with many other major humanitarian actors, Save the Children has in recent years increasingly focused on partnership with private capital. Through what it terms its Global Corporate Partnerships, the organization works "toward positively addressing the unique and complex challenges facing children, their families and communities, while simultaneously creating value for partners' businesses and brands" (Save the Children 2016a, 8). Such collaboration brings together "marketing teams on cause-aligned campaigns and licensing programmes that leverage the power of our combined brands and consumer reach" to create "industry coalitions on mutual areas of interest, bringing collective support to large-scale projects"(Save the Children 2016a, 8). As touched on in the first chapter, inherent problems arise in such collaboration and marketization and the problematic interplay between humanitarian aspirations and business objectives. The implication of combining business goals - and their inherent interest in economic profit - with relief intervention raises questions about the extent to which humanitarian objectives need to be negotiated and accommodated to allow such collaboration. The collaboration with private capital is not only an organizational strategy that can benefit NGOs or UN agencies. What needs to be grasped are the implications that such interplays can have on the practical consequences that humanitarian interventions have in the context in which they occur.

\subsubsection{Save the Children and Syrian Displacement}

Save the Children, which has had programs in the Middle East for decades, has been strongly involved in the humanitarian response to the Syrian war. The organization has been operational both within Syria and in neighboring countries of refuge (principally Jordan, Lebanon, Iraq and Egypt), along the eastern Mediterranean route, 
popularly known as the Balkan route (i.e., Turkey, Greece, Serbia Croatia, Italy), ${ }^{4}$ into preferred countries of asylum in northern Europe (e.g., the Netherlands, Germany and Switzerland), and in the Mediterranean.

Between 2015 and 2016, the bulk of Save the Children work in countries hosting Syrian refugees mainly focused on child protection and education. The organization established several child and youth friendly spaces - both in camps and in urban areas - where children were offered recreational activities and psychosocial support services to help cope with the traumatic experience of war and displacement. Save the Children supported host governments to offer formal education to eligible Syrian refugees. For those children who could not enter the formal education system (because of lack of documentation or financial resources) the organization provided non-formal and remedial education. Though not a major player, Save the Children also distributed food and basic relief items, provided cash assistance, organized activities seeking the economic empowerment of vulnerable hosting communities and implemented water and sanitation, and shelter rehabilitation projects.

Although at first sight quite technical activities, different interventions have important implications for the way in which NGOs participate in global governance and particularly, as in this case, how they contribute to the shaping of the governance of refugees. For example, Save the Children's emphasis on psycho-social support activities is part of a logic that Pupavac (2001b) has defined as " "therapeutic governance". Psycho-social interventions, culturally deeply rooted in the AngloAmerican therapeutic ethos, are centered on social risk management strategies. The basic assumption of the psycho-social model is based on the vulnerability of the individual, and particularly the vulnerability of women and children, with quite limited attention to adult males and with scant regard for the specific social roles in war and displacement. Refugees, either seen as traumatized or alternatively in denial of their trauma and susceptible to be re-traumatized by memories, are inevitably considered dysfunctional. "As a consequence of the pathologisation of their condition, psycho-social intervention implicitly denies the capacity of populations for self-government" (Pupavac 2001b, 365) and may severely undermine local coping strategies. Moreover, the pathologisation of war-affected communities implies refugees' disqualification as political actors, while at the same time "validating the role of external actors", namely the humanitarian organizations (Pupavac 2001b, 367). This perspective is important not only because it highlights how the psychosocial model resonates with colonialist approaches characterized by the pathologization of the dependent subject, but also for its insight into the focus on children that Save the Children shares with many other organizations. Drawing on Burman's work, Pupavac (2001a) has pointed out how the emphasis on children has contributed to the reproduction of a stereotyped idea of an adult professional from the Global North helping and supporting an infantilized subject in the Global South.

\footnotetext{
${ }^{4}$ The eastern Mediterranean route was the most-used pathway for Syrians attempting to reach Europe between 2015 and 2016. For more information on what as became popularly known as the Balkan route, see Achilli 2016.
} 
In 2016, in response the growing number of people losing their lives trying to cross the Mediterranean en route to Europe, Save the Children established its own maritime SAR operation, chartering a vessel which operated until SAR was abandoned following repeated clashes with the Libyan coastguards. Although as Cuttitta (2017) has observed, SAR operations have a substantial impact in both the depoliticization and repoliticization of the EU maritime border, Save the Children's political positioning on its SAR activities was one of political neutrality, the agency investing much effort in trying to keep politics separate from its life-saving activities.

In addition to its work in the field, the organization is also committed to advocacy and global campaigning. Syria is one of the sites of Save the Children's biggest campaign, Every Last Child, that focuses on the world's excluded children, with a campaign website dedicated to the children affected by the Syrian crisis (Save the Children 2018g). Different operational branches engaged in several social, communication and fundraising campaigns specifically focusing on Syria. These included: child refugee crisis (Save the Children 2018c), the space migrant (Save the Children 2018d), most shocking second a day (Save the Children 2014), still the most shocking second a day (Save the Children 2016d), and numerous hash tags such as \#iostoconAylan, \#NotJustARefugee, \#savechildrensatsea, \#SaveChildRefugees.

Save the Children also played a major role in the various fora gathering together international organizations working on the Syrian response and particularly in their advocacy working groups. The organization has been a signatory of several collective NGO advocacy documents such as Failing Syria (Various NGOs 2015) and Stand and Deliver (NGOs Platforms et al. 2017). In relation to the so-called European refugee 'crisis', SCF produced an advocacy report summarizing the key priority recommendations at EU, regional and national levels (Save the Children 2017). Politics is quite clearly called into question in the organization's advocacy strategy as those documents address the context of the war. However, policy recommendations are presented in a consciously apolitical and technical discourse

\subsection{Oxfam}

Oxfam International was established in 1995 by a group of NGOs. The name Oxfam emerged from an initiative in 1942, the largely Quaker-inspired creation of the Oxford Committee for Famine Relief, founded in 1942 advocating for food supplies to be sent to women and children suffering famine in war-torn Greece (Barnett and Weiss 2008) The organization rose to prominence during the war for Biafran independence at the end of the 1960s when it chose to disregard Nigeria's land and sea blockade of Biafra and organized an airlift. In striking contrast with the policy of the International Committee of the Red Cross (ICRC) to remain neutral and to respect the sovereignty of the Nigerian state, OXFAM took an explicit partisan position affirming that "the price of a united Nigeria is likely to be millions of lives" (De Waal cited in Chandler 2002, 30). Today Oxfam International is a confederation 
of 20 affiliated organizations around the world and maintains an international secretariat in Oxford. It works in 90 countries across five continents, focusing on fighting poverty and inequality through projects based on active citizenship, natural resources, women rights, access to services, life-saving activities and sustainable food (Oxfam International 2018d).

The organization defines itself as independent and impartial according to the following definitions adapted by the ICRC: "Impartial: for every person, according to their needs, without discrimination because of race, gender, religion, age or anything else; and Independent: directed without influence from any interest group or political group' (Oxfam International 2013, 2). Oxfam, like SCF and other major humanitarian players also is committed to Sphere standards, The Code of Conduct for the Red Cross and Red Crescent Movement and NGOs in Disaster Relief, and the Core Humanitarian Standards. It also, like other NGOs, has signed up to Do no Harm Principles, stating that "the humanitarian imperative does NOT mean that we (...) should provide assistance without considering whether its harm could outweigh its benefit. We must judge the likely immediate and long-term consequences of different actions before deciding how, and whether to provide aid' (Oxfam International 2013, 2).

On neutrality, Oxfam presents a particular perspective as it links the term to its advocacy role and the possibility to speak out in cases of extreme suffering or violation of people's rights. In the words of the organization: "impartial advocacy does not mean saying that every party to violence is always equally to blame. Nor is Oxfam neutral in the sense of avoiding anything that could be construed as a policy controversy. We take a stand on the causes of humanitarian need and propose policy changes to solve them - based on our experience, values, and international humanitarian law. Speaking out Oxfam routinely bears witness to extreme suffering and violations of people's rights under international humanitarian, refugee and human rights law. This is part of our responsibility to raise the voice of those affected, alert the world, and call on relevant authorities to take action. Usually we do that in public, but sometimes that may create unacceptable risks to the safety of our staff and others, or to our ability to provide assistance. Judging when and how to speak out is never easy. Campaigning can be vital to ensure people can reach the aid that they need. But we may also have to negotiate with parties to a conflict, in order that affected men, women and children can reach the assistance they need. And that may require us to limit our campaigning or to support other organisations rather than 'speak out' as Oxfam ourselves" (Oxfam International 2013, 3).

Oxfam's major source of income is from institutions (41.4\%), followed by public f $(39.6 \%)$, trading revenue $(17.5 \%)$, and other incomes $(1.1 \%)$ for a total of 1.05 billion Euro. Within the expenses relating to programme implementation, $52 \%$ is spent on development and humanitarian activities, and $6 \%$ on influencing activities (Oxfam 2017b).

Like Save the Children, Oxfam has considerably expanded from its original objective of addressing famine. The agency has sought to position itself as willing to oppose state policies. This self-perception and self-positioning of Oxfam is indicated by its emphasis on humanitarian principles and particularly on its vision of 
neutrality and the need to speak out. From a financial perspective, Oxfam is not as independent as it likes to imply it is. Unlike, for example, MSF, Oxfam is heavily dependent on UK and EU funding. This accounted for $43 \%$ of income in 2017.

\subsubsection{Oxfam and Society}

Oxfam's Strategic Plan (Oxfam 2013) lists the organization's key priorities: “change our world", "tackle poverty", and foster "lasting resilience to crisis and poverty". Central to Oxfam's approach is the concept of "transformational change", the longterm goal to address the root causes of poverty through structural practices policy changes. Oxfam's vision is of "a just world without poverty (...) a world where people are valued and treated equally, enjoy their rights as full citizens, and can influence decisions affecting their lives" (Oxfam 2017a). In order to achieve this, Oxfam seeks to "create lasting solutions to the injustice of poverty. We are part of a global movement for change, empowering people to create a future that is secure, just, and free from poverty" (Oxfam 2017a).

It is quite clear from the organization's own statements how the agency sees its role as key in global governance. Its position is clearly summarized in the section outlining the organization's beliefs: "We face unprecedented changes and challenges this century, including climate change, famines and food price crises, increasing humanitarian crises, energy limitations, proliferation of weapons, urbanization, and natural resources shortages. To meet these challenges, we need global cooperation and cohesion. Governments should be accountable to their people, and all society's institutions - corporations, organizations and groups including us - should be accountable for the impact of their actions" (Oxfam 2017a).

The creation of a worldwide influencing network (including the further development of communication, advocacy and digital strategy) is one of the key priorities envisaged for this transformational shift. Oxfam's work on global campaigning whether on climate change, displacement or sustainable development - makes use of celebrities to disseminate messages worldwide with all the implications already discussed for Save the Children in this regard.

Oxfam International is committed to both humanitarian and development work, declaring that "as well as becoming a world leader in the delivery of emergency relief, Oxfam International implements long-term development programs in vulnerable communities" (Oxfam International 2018b). Oxfam does not only define itself as a development organization that is also working in humanitarian response but considers humanitarian action as a "work that integrates life-saving response with building resilience" (Oxfam 2013, 11). The link between humanitarian action, human security and development is explicitly stated in the Strategic Plan goal 3 "Saving lives, now and in the future", where the specific objectives include, beside the provision of humanitarian assistance, resilience, institutional capacity building for human rights protection and women's rights. 
In order to achieve its goal, the organization applies a "combination of rightsbased sustainable development programs, public education, campaigns, advocacy, and humanitarian assistance in disasters and conflicts" (Oxfam 2017a). The rightsbased approach is among the organization's guiding principles (Oxfam 2013). Within Oxfam, human rights are perceived as an operational concept: respect for human rights is t considered a prerequisite in the fight against poverty and inequality. Oxfam asserts that it has operationalized the human rights approach into its work around livelihoods, access to basic services, protection, the right to be heard, and inclusion. As with Save the Children, the combination of humanitarianism with development and the embracement of a rights-based approach indicate the role that Oxfam wants to play in global governance.

There are a further two other elements which the organization considers fundamental and characteristic of its action: making people's voices heard and empowering them (especially women). On its website, Oxfam International represents this two-fold approach to fighting poverty by two icons. The first symbol (a megaphone) refers to the ability of people to claim their own rights: "When people have the power to claim their basic human rights, they can escape poverty - permanently. This core belief underpins our development programs in more than 90 countries. With our partners, allies and with local communities, we help people to claim rights for themselves" (Oxfam International 2018c). Expressions referring to the importance of making people voices heard to affect social change are consistently repeated throughout Oxfam's strategic documents. “Oxfam's Strategic Plan to 2019 has a vision that sets local communities and the voices of women, men and young people at the centre of change" (Oxfam 2013,5); "we will put a particular focus on gender justice and empowering poor people to make their voices heard" (Oxfam 2013, 8); "Oxfam believes that people living in poverty who claim their rights and make their voices heard constitute an enormous source of hope for real change and greater power in people's lives" (Oxfam 2013, 9); "Bring the voices of poor and vulnerable communities into debates about development and prosperity" (Oxfam 2013, 19). The second icon, the stylized figure of a woman with a speech bubble, indicates women empowerment, which symbolically is, again, represented by the ability to speak out: "Human development is driven by empowered women. But women and girls are still massively underrepresented and often oppressed. We work to help them speak out and demand justice, and to assert their leadership." (Oxfam International 2018c).

The empowerment of people and giving them voice is fundamental to Oxfam's public identity (as it is with many other NGOs) and was frequently mentioned by my interviewees. This is an important point that will emerge again in the analysis of NGOs' communication material. It is important to note that the empowerment of people through their own voices is far from unproblematic. By focusing on an Oxfam project developed exactly for this purpose, entitled Listening to the Displaced, Rajaram (2002) has pointed out how the organization's representation did not manage to distance itself from more traditional depiction of refugees "in terms of helplessness and loss". Far from allowing displaced people to speak for themselves and account for their individual experience of displacement, the project, 
rather, reproduced an image of refugees in de-politicized and de-historicized terms. While acknowledging Oxfam's admirable intention to challenge the systematic silencing of refugee identity, the scholar noticed how the "particular bureaucratized knowledge about refugees and the methodology for "listening' to them" (Rajaram 2002,248 ) concur to a sense of objectivity and distance that conceal the author as mediator in the publication of refugee experiences. The refugees' voices, included in the project to understand displaced people' personal perspective and empower them, are not only reduced to those of humanitarian subjects, but they are also denied the right to account for their experience in politically relevant terms. In the new humanitarian rhetoric around making people's voices heard, of which Oxfam is a prime exponent, Western systems of meaning are thus reproduced. (Rajaram 2002).

For Oxfam advocacy plays a fundamental role in the organization's aspiration to play a major role in changing the world. The influencing component of Oxfam's strategic programme is seen as part of its strategic objective as much as development and humanitarian response. Influencing is judged to be crucial to the achievement of their long term development goals and humanitarian achievements. According to an Oxfam advisor interviewed for this study: "we are knocking at every door to influence what we are campaigning for: different parties, ministries, donors, Heads of States, despite their political colour. At the end of the day, it is always about rights. If politics helps the cause for rights, we will work with it. Of course, we do a lot of context analysis, power analysis, stakeholder analysis. But, for instance, also in the case the European Migration Campaign and the political position of EU to close its borders, of course we take money there - even though EU gives the money in the neighboring countries to keep the refugees there. We anyhow take the money to address the needs. Oxfam is big, we can still work on the humanitarian side and the advocacy side at the same time. Then, of course, different Oxfam offices may decide to take money from some government because they are trying to influence it and they want to remain independent. For instance, Oxfam USA does not accept USAID money (but this is linked to advocacy on domestic issues)." ${ }^{\prime 5}$ This quotation clearly shows how the intention to be operative on the ground and able to influence decision makers helps determine the extent to which Oxfam interacts with politics, donors and their policy agendas.

The possibility of overcoming political differences is based on the focus on rights, considered as something neutral, distinct from politics, a sort of technical field to which Oxfam can appeal to in order to avoid open reference to power and politics. The statement also underlines the crucial way in which Oxfam perceives its role in global governance: as an organization 'big enough' to be able to implement humanitarian work (portrayed as exogenous to the political realm) with advocacy (considered as openly political).

In order to achieve transformational change, over the last decades, Oxfam has developed strategies that complicate even further the already complex relationship that the organization has with power. On the one side, Fassin has pointed out how

\footnotetext{
${ }^{5}$ Interview with Oxfam Policy Advisor, 8th March 2017, Beirut.
} 
Oxfam is the example of what he defines a "paragovernmental agency". As he explains, "humanitarian intervention has become a policy of nation states, whether because governments are developing their own activity in the field (France, for example, has had several ministers for humanitarian aid) or because they delegate it to paragovernmental agencies (such as the Oxford Committee for Famine Relief [Oxfam] in the United Kingdom)" (Fassin 2007, 508). Oxfam, like other major NGOs has been increasingly working in partnership with private capital. As Barnett and Weiss (2008) have argued, the problematic aspect of this collaboration revolves around the values and practices that dominate the social mechanism of the market, where everything is given a price. Therefore, they ask, how can humanitarian practitioners accommodate humanitarian principles with the calculations of the market? In both cases, it is evident how the NGO works in a complicated environment where there are political and economic interests at stake that eventually affect, in one way or another, not only the aspirations of the organization, but also its practical work on the ground role in the international community. As previously discussed in relation to SCF, dependence on government funds and collaboration with private capital are not without consequences. Whereas it appears quite straightforward that national interests, private capital and humanitarian action are inspired by quite diverse logics, their strict interrelation raises also questions regarding the NGO's space of manoeuvre in carrying out activities that may present a conflict of interests, an apparent threat to agency emphasis on maintaining independence. While Fassin's definition of Oxfam as paragovernmental may seem exaggerated, the implications of depending on institutional funding and working in collaboration with private capital cannot be underestimated.

\subsubsection{Oxfam and Syrian Displacement}

Oxfam works with people whose lives have been affected by natural or humaninduced disasters around the world. Thus Oxfam is active in many displacement contexts, primarily providing water, food, sanitation and protection services. With regard to those affected by the Syrian war and displacement, the NGO operates in Greece, Italy, Jordan, Lebanon, (North) Macedonia, Serbia and Syria. Inside Syria, Oxfam has been working on the rehabilitation of water infrastructure, provision of clean water, public health promotion, solid waste management and supporting livelihoods. In Syria's neighboring countries, Jordan and Lebanon, the organization's intervention has been focused on water, sanitation, cash assistance and service information/referral projects to advise people about their rights and refer them to the most adequate support services. Along the migration route, Oxfam has worked with newly-arrived people by providing assistance (water and sanitation facilities) and protection (psychosocial support and legal counselling) in Serbia and (North) Macedonia. In Italy and Greece, the organization has distributed food and non-food items and provided psychological and legal support to those in need. 
Alongside this emergency response the NGO works to influence policy makers to promote the changes needed for the improvement of refugees' lives Influencing plays a pivotal role also in its emergency work. In Oxfam's words: "Providing lifesaving support to the millions of people affected by this devastating conflict is essential but it is not enough. We have been campaigning and advocating for an end to the fighting, and a sustainable and inclusive political solution since the beginning of the crisis. The continued violence, bloodshed and suffering in Syria represents a catastrophic failure by the international community to bring peace and security. We will continue to call on all parties to the conflict to commit to ending the massive violations, stop any arms transfers and guarantee humanitarian access and protection of civilians, whether inside Syria or in neighbouring countries" (Oxfam International 2018a).

The organization also carried out several social communication campaigns such as Protect the lives of refugees and migrants (Oxfam 2016b), or Join hands \#withSyria (Oxfam 2016a), through which it asked people around the world to share selfies with the dove symbol to indicate solidarity with Syria. As part of the more overtly political Syria Refugee Crisis: Is your country doing its fair share? (Oxfam 2016c), the agency urged EU member states to do more in terms of resettlement.

The analysis of the work that Oxfam carries out in response to Syrian displacement has highlighted that the organization has been mainly focusing on two streams of action. The first, based on relief assistance in line with traditional emergency support (e.g., provision of basic services) has also been combined with psychosocial support within the more holistic perspective of the rights-based approach. The NGO has sought to realise aspirations in its programmatic documents for a comprehensive and sustainable response to human suffering. This approach underlines Oxfam understanding of its role within the global governance regime for displaced people and that it should not be confined to provision of water and building of latrines, but involve active engagement in promoting and protecting peoples' rights. This stream of action is more explicitly political. It openly speaks to state politics and is embedded in Oxfam's stated commitments to the humanitarian principle of neutrality and need to speak out on human rights violations.

\subsection{CARE}

The Cooperative for American Remittances to Europe (CARE) was founded in 1946 by 22 US-based charity organizations with civic, labour, and faith-based backgrounds. Like SCF and Oxfam, its initial scope was to provide food assistance to people suffering famine in the aftermath of World War II. Once post-war Europe was on the road to recovery CARE became operational in Asia, and subsequently in Latin America and Africa. In addition to food relief, CARE started to provide medical support and non-food-item assistance to people affected by conflicts. To represent the wider geographical extent of its operations, it changed its acronym to the Cooperative for American Relief to Everywhere. By the 1970s it had expanded its 
areas of intervention from immediate assistance to long-term programs of recovery and rehabilitation. Like many other NGOs it became increasingly focused on female inequality in the 1980s and today has an explicit organizational focus on gender. There was a further re-branding in 1993 when its acronym was again changed to the Cooperative for Assistance and Relief to Everywhere. Today CARE International is a confederation of 14 member organizations (with seven candidate and affiliate offshoots). It works in over a 100 countries, mainly focused on food security, education, health and community wellbeing, women's economic empowerment, water and sanitation.

With regards to humanitarian principles CARE defines itself as an agency which is "Independent of political, commercial, military, ethnic or religious objectives CARE promotes the protection of humanitarian space. We provide assistance on the basis of need, regardless of race, creed or nationality addressing the rights of vulnerable groups, particularly women and girls" (CARE 2017). CARE, like SCF and Oxfam, similarly adheres to the international guidelines and statements of principle mentioned above. CARE respects a set of internal Programming Principles which include promoting empowerment, working in partnership with others, ensuring accountability and promoting responsibility, addressing discrimination, promoting non-violent resolution of conflicts, and seeking sustainable results.

CARE International aggregated income amounts to 725,640 million euro. Sixty four per cent of revenue in 2016 came from government and institutional grants, other donor contributions (27\%), in kind (6.5\%) and other income (2\%) (Care International 2017). Expenses are divided among development activities (57\%), humanitarian activities (28\%), and supporting services (14\%) (Care International 2017).

\subsubsection{CARE and Society}

CARE's work, combining development and humanitarian assistance programmes, aims at ending poverty so that people can "live in dignity and security" (CARE 2017). CARE International's Programme Strategy focuses on reducing poverty, understood as the result of power imbalances and social injustice (CARE 2014). The organization considers gender inequality and humanitarian crisis as two main factors in producing injustice and insecurity in the world. CARE's humanitarian action is combined with development and resilience-building objectives to achieve lasting impact. Specifically, the organization humanitarian goal for 2020 is to "to continue to strengthen our humanitarian work to have a lasting impact for people affected by humanitarian crises, with a special focus on women and girls' (CARE 2016a, 2). As Barnett has noted, CARE, like SCF and Oxfam "began as relief organizations and thus initially saw themselves as part of the humanitarian system, once relief was no longer a priority they soon tackled reconstruction and development activities and no longer identified as closely with a "humanitarian" system still very much defined by relief" (Barnett and Weiss 2008, 5). 
The role that the organization acknowledges for itself in global governance is confirmed by several statements disseminated in official documents, such as: "CARE recognizes it must continue to lead and contribute towards guaranteeing that globally humanitarianism plays an essential role in overcoming social injustices and inequality" (Care International 2016, ii). In order to achieve its mission, the NGO works in collaboration with the private sector, and it proudly presents the corporate partners and commercial brand with whom it collaborates (CARE 2018b).

In all its programs, both in development and humanitarian settings, CARE has a focus on women and girls. According to the organization, poverty and discrimination affect women disproportionally and therefore the NGO has decided to pay particular attention to gender empowerment. For CARE the gender approach is intended as a particular attention to the needs of women and girls rather than in its wider meaning, as an approach sensitive to any gender difference. In CARE's words: "globally, social injustice and gender inequality leave women highly vulnerable and disempowered to protect themselves during disasters and to reduce their risk to future disasters. Women and girls struggle to be heard and to be given the opportunity to make decisions that could save themselves and their families and communities during disasters." (Care International 2016, iii). In practice, this translates into long-term sustainable development programming to "create sustainable transformative changes in gender equality (...) CARE therefore strives to embed gendered disaster responses, disaster risk reduction (DRR), resilience and climate change adaptation as part of its long-term programming to address social injustices, weak governance and vulnerability. Failure to do this can undermine any impact achieved through humanitarian or development programming, or worse yet lead to 'double disasters' especially in terms of GBV [Gender Based Violence] against women and girls during crises and in the transition from relief to recovery due to the possibility of socially disrupted or destroyed households and communities" (Care International 2016, 16).

CARE's focus on gender is relevant when trying to grasp the role that the organization wants to have in global governance. There are a wide range of approaches that look at the production and reinforcement of gender inequality and attempts to challenge them. According to the United Nation agency dedicated to gender equality and the empowerment of women (UN Women) the different approaches can be situated along a spectrum that goes from gender neutral, an approach that does not reinforce existing gender inequalities, passing through gender sensitive, programs aimed at redressing existing gender inequalities, to gender transformative, approaches that attempt to re-define women and men's gender roles and relations. (UN Women 2018). In this sense CARE has definitely embraced the gender transformative model, "transforming the power dynamics and structures that serve to reinforce gendered inequalities" (Hillendrand et al. 2015).

Such contemporary emphasis on women's rights has been criticized as a neocolonialist and culturalist approach that considers the Western perspective as the universal standard to which other societies should adhere for their own good (see among others, Abu-Lughod 2002; Mahmood 2011; Grande 2016). Grande has argued that humanitarian discourse on women rights" functions as a powerful agent 
of social individualization" (Grande 2016, 78), whereby only women' individual rights are promoted and protected - in line with the Western understanding of human rights - while collective rights are dismissed as not really in the interests of women and always assumed to have been socially imposed on them. In this cultural reading, humanitarian organizations intervene to transform power dynamics that do not match with their own cultural background. Besides the obvious neo-colonialist and culturalist implications of such an approach, the problem, insightfully pointed out by Grande, is that women rights discourse advances a message strongly based on individualization rooted in neoliberal logic one which structures and discourses based on collective rights.

The gender transformative perspective is part of the wider rights-based approach embraced by the organization and explicitly mentioned within the principles of the organization (CARE 2017). The attention to rights is pivotal in two of the three main core elements of CARE's approach: Strengthening Gender Equality and Women's Voice and Inclusive Governance. Within the framework of the latter, the organization works on women empowerment and transform unequal power relationships, 'based on CARE's commitment to the rights of all people to live free from poverty'. The NGO places 'particular emphasis on strengthening the voice of women and girls and enabling them to influence the decisions that affect their lives. We support women's struggles to achieve their full and equal human rights, including girls' right to education. This includes balancing practical, daily, individual achievements with long-term efforts to challenge unequal social rules and institutions' (CARE 2018a). Beside the focus on women empowerment that I have already discussed in the previous paragraph, it is clear from these kinds of affirmations how the rights-based approach is entangled with the aspirations the NGO has in terms of society transformation and its role in global governance. Under the second element of

CARE seeks to play an active role in global governance, arguing that "CARE promotes inclusive governance in three key ways; by empowering poor and excluded people to know and act on their rights and represent their interests; by influencing those in power, such as governments, traditional leaders in the private sector, to be more responsible, responsive and accountable; and by brokering linkages and convening spaces which enable effective and inclusive relations and negotiation between the two" (CARE 2018a).

My interviews indicated that the complex relationship that the organization has with politics and global governance is not unknown to its staff, who, on the contrary is very aware of the risks and the opportunities implied in this complicated relationship. As a CARE communication and advocacy staffer affirmed: "let's start by stating that CARE is apolitical. Of course, the situation on the ground is more complex. And we must also say that all communication is political. For example, take the case of the safe zones in Syria and the debate in Lebanon around the Syrian refugee return to those zones. CARE would publicly say that they do not go into politics, that UNHCR is dealing with these kinds of issues, that the war at the moment is not over. They would always make the point. At the same time, since this is a very sensitive issue in Lebanon, and the Lebanese population has been very welcoming with the refugees, CARE would not say that they are against safe zones because Lebanese 
public opinion would be very against such a position (because, let's be clear, they want the Syrians out). So, in order to avoid politics, CARE would take a human rights approach, saying that if there is a legitimate authority (such as the UN) that guarantees the safety and security of those zones and the fact that Syrians are moving to those zones under no coercion or incentives, in that case, we would support the idea. (...) Politics goes into that whether we like it or not. But we take a human rights perspective, we do not talk about politics."

Once again, the realm of human rights is considered a neutral and technical dimension that the organization can appeal to in order to avoid interconnections with politics. Interestingly, while this account confirms high level of staff reflexivity around the complexity and dilemmas of the relationship between humanitarianism and politics, it seems at the same time to disregard that human rights discourse is intrinsically political.

This is important especially in relation with the literature that has offered a classification of the major humanitarian organizations according to their relationship with politics (see Chap. 2). In all different studies, CARE is always one of the organizations positioned furthest from the 'complete-independence-from-politics' end of the spectrum. Stoddard has classified CARE as typically Wilsonian (Stoddard 2003, 28). Similarly, Barnett (2009) has used CARE as a paradigmatic example of an alchemic and dependent organization, one that aspires to address the root causes of suffering while being dependent on State funding and agendas. Alchemic organizations like CARE rebuff accusations of being too close to States by framing political interventions in technical terms Analysis of CARE documents and interviews with CARE staffers confirmed this.

Interestingly, however, for some CARE staff the role of the organization vis a vis global governance depends, at least to a certain extent, on the level of their office, whether national, regional or international. As a CARE emergency coordinator told me when asked how she understood CARE's role in global governance: "I am not sure how to answer this question because the field is the last level of CARE organization. Talking about global governance you should talk to the people who work at the international level." Similarly, discussing the complicated relationship of humanitarian action with politics, she noted that: "for CARE Greece it is not a very big issue. It is different for national and international NGOs because in our case any advocacy product that could have any political implication goes through CARE Geneva. At the national level, our work is not affected by politics or the political situation because our advocacy anyhow is not targeting the Greek government but EU members." 7

Although highly aware of the key role that the NGO plays in the international arena, indeed taking it for granted, what the NGO staff I talked to suggested that humanitarian action had political implications at the highest international level,

\footnotetext{
${ }^{6}$ Interview with CARE Communication and Advocacy Manager, 7th March 2017, Beirut.

${ }^{7}$ Interview with CARE Emergency Coordination Officer, 13th June 2017 via Skype.
} 
while at the local level, it constituted an intervention only related to providing aid, something seen as disconnected from politics and any particular role in global governance.

\subsubsection{CARE and Syrian Displacement}

CARE International works with displaced Syrians and host communities in Syria, Jordan, Lebanon, Egypt, Turkey, Greece and the Balkans. In Syria CARE has provided life-saving assistance and education services, distributing food and non-food items (NFIs) while building capacities of local organizations providing assistance on the ground. In host states CARE has focused on protection, distributing relief items, and water and sanitation. It has provided psycho-social support to women, men and children to help them cope with their experience of trauma, loss, and gender-based violence (GBV). CARE has provided information on how refugees can access health, legal and social support, and organized raising awareness sessions on GBV, child protection, and early marriage. Protection services have been provided in Jordan, Egypt and to a lesser extent in Turkey. CARE has also distributed emergency cash assistance (in Jordan, Lebanon, Egypt, and Turkey), hygiene kits and dignity kits for women and older people (Lebanon and Turkey), food (Turkey), non-food items (Turkey, and Lebanon), and water and sanitation (Lebanon and Turkey). In the Balkans and in Greece, CARE has distributed food and NFIs and supported the establishment of centres where information and translation services are provided by volunteers.

It should be noted that CARE's gender transformative programming has consequence for the role that the organization seeks to play in global governance. Far from wanting to contest the importance of gender sensitiveness on a general level, it is rather important considering the social implications of an approach based on such specific socio-cultural premises completely different from the area of intervention. In other words, the political consequences of a self-proclaimed technical and universal rights-based approach of a Western-based organization (with a transformative agenda) into the social dynamics of a Middle Eastern context needs to be acknowledged and understood into the framework of the role that CARE plays, and intends to play into global governance.

CARE appears to have been the only of the four studied NGOs to have set up specific Twitter (CARE 2012) and Facebook (CARE 2016b) pages around its response to the Syrian crisis.

Through social media CARE has launched such campaigns as Dear World - We are People ('Syria Crisis: Dear World - We Are People' 2016) and What Would you Take? (CARE 2016c) with the hash tag \#Syria2000days. CARE's advocacy conforms with what Chouliaraki has defined "post-humanitarian communication"(Chouliaraki 2010), a strategy that has abandoned the focus on pity and grand-emotions for a more playful engagement that makes the spectator's emotions the measure of the understanding of the suffering of others. 


\subsection{Médecins Sans Frontières}

Médecins Sans Frontières (MSF), was founded in 1971 in France by a group of volunteers, including doctors and journalists Among its 14 founders the most prominent was Bernard Kouchner, a French doctor, who at the time of the Biafra crisis, was working for the ICRC, but resigned in protest at the ICRC's failure to speak out against Nigerian government tactics to starve Biafran secessionists into submission. For Kouchner, ICRC and its staff were "accomplices in the systematic massacre of a population" (Kouchner cited in Chandler 2001, 684). Chandler (2001) has argued that the rise of MSF to global prominence has introduced two new humanitarian principles. The first has to do with the principle of denunciation that is today one of the agency's fundamental principles. The concept was so defined by James Orbinsky when MSF was awarded the Nobel Peace Prize in 1999: "silence has long been confused with neutrality and has been presented as a necessary condition for humanitarian action. From its beginning MSF was created in opposition to this assumption. We are not sure that words can always save lives, but we know that silence can certainly kill". (Orbinsky cited in Chandler 2001, 685). The second principle, and one that was subsequently confirmed by NGOs going into Iraq, Myanmar and other contexts in defiance of State prohibitions on access, is the right to intervene, disregarding state sovereignty in the name of higher principles of humanity

MSF may have emerged in opposition to what Kouchner regarded as ICRC's passivity but, nevertheless, MSF is firmly rooted within the Dunantist tradition based on the principle of independence of humanitarian action (Tong 2004). MSF has stated that its "actions are guided by medical ethics and the principles of impartiality, independence and neutrality" (MSF 2018a) and "claims full and unhindered freedom in the exercise of its functions. (MSF 2017b)". As Tong (2004) has pointed out, these principles are understood in a pragmatic way, that takes account of contextual complexities in which humanitarian aid is needed and delivered MSF assets that to respond to the humanitarian imperative it may be necessary to privilege the principles of impartiality or independence over that of neutrality. In other cases, the organization can decide not to intervene or withdraw from an emergency when there is the possibility that aid is contributing to the perpetration of violence.

Although MSF has signed the Code of Conduct for the International Red Cross and red Crescent Movement and NGOs in Disaster Relief, it has withdrawn from Sphere fearing the project overemphasizes quality and accountability indicator to the detriment of considerations around political contexts and power dynamics (Tong 2004).

By distancing itself from Sphere and the UN Cluster System MSF may act as if it is a humanitarian outsider, but it has become a powerful and well-funded movement. Now comprising 25 sections (recently renamed by MSF as associations), the agency is active in over 80 countries across the world. Given the exclusive focus of the organization on humanitarian activities, the $80 \%$ of the total income of 1,5 billion Euro devoted to relief activities. As opposed to the other organizations selected for this study, and indeed almost all other international NGOs, MSF 
overwhelmingly depends on private individuals donating small sums, $95 \%$ of its funding in 2017. Since 2016 MSF no longer accepts funding coming from any EU member States and Institution in protest against European migration policies (MSF 2016h). MSF identity is rooted in its assertion that the agency "remains fiercely independent of both governments and institutions" (MSF 2018c). The strategy of relying on non-state funding from multiple supporters has consequences, requiring a consistent and resource consuming attention to fundraising and maintaining contact with myriad supporters.

\subsubsection{MSF and Society}

Unlike the three other NGOs studied here, MSF focuses only on medical humanitarian assistance. The organization intervenes in situations of armed conflict, natural disaster, endemic and epidemic diseases, social violence, and healthcare exclusion. It offers basic healthcare, carries out vaccination campaigns, performs surgery, fights endemics, rehabilitates and runs hospitals and clinics, operates nutrition centres, and provides mental healthcare. Where necessary the organization sets up sanitation systems, supplies safe drinking water, and distributes relief (MSF 2018d). Because it has traditionally focused on humanitarian assistance MSF has been classified as" single-mandate" organization, against" multi-mandate" agencies combining humanitarianism with development (Tong 2004). As Tong has observed, this does not mean a complete dismissal of a long-term perspective, but rather its sidelining in the name of immediate needs.

Although scholars (Chandler 2001; Barnett 2009) have defined the NGO as a rights- based organization, they have also later noticed how after the intervention in Afghanistan in the 2000s, MSF changed direction refusing to participate to reconstruction programmes and going back to a need-based approach ${ }^{8}$ (Barnett 2009). MSF's preference is confirmed by the paper that MSF presented at the World Conference of Humanitarian Studies (DuBois 2007) that outlines the organization's criticism of the right-based approach. It is further indicated by MSF's statement that "We offer assistance to people based on need. It doesn't matter which country they are from, which religion they belong to, or what their political affiliations are. We give priority to those in the most serious and immediate danger"' (MSF 2018a). A needs-based approach underpins its work, endeavouring whenever possible, to close operations as soon as life-saving needs are over. As explained by MSF, "the closure of a programme reflects MSF's specific mandate to provide medical humanitarian assistance. The decision to withdraw is based on our experience and analysis of the

\footnotetext{
${ }^{8}$ As Barnett (2009) illustrated, humanitarian organizations active in Afghanistan become increasingly involved in governance activities, promoting democracy and human rights and connecting their relief work with the reconstruction operations. Although MSF had already included longterm activities within its humanitarian work, the organization refused to participate in reconstruction programmes on the basis that they were incompatible with their humanitarian mandate.
} 
situation, and the imperative to make choices so that we can devote our assistance to the most vital needs" (MSF 2018b).

For MSF, speaking out or témoignage (bearing witness) is a fundamental aspect of the agency's identity. and has become one of the distinctive characteristics of the organization since its origin. This is intended as "an effort to bring a forgotten crisis to public attention, to alert the public to abuses occurring beyond the headlines, to criticise the inadequacies of the aid system, or to challenge the diversion of humanitarian aid for political interests" (MSF 2017a). While MSF has firmly affirmed its neutrality and impartiality Slim has classified the agency in terms of "active impartiality"' (Slim 1997, 349). According to the author, MSF's specific interpretation of the principle of impartiality does not have to do with the various parties involved in a conflict, toward which the organization will always maintain its impartiality, but has rather to do with the actions of the various factions. In cases the NGO observes human-rights abuses, it will publicly speak out to denounce or condemn the violation.

Also, advocacy and campaigning play an important role in the organization. Similarly, to the other three NGOs, MSF dedicates a crucial attention to campaign activities. The organization's campaigns have mainly focused on specific health issues, such as medicine access (MSF 2016a), and drugs prices and patents (MSF $2016 \mathrm{~b}, \mathrm{f}$ ), or more related to broader humanitarian issues such as the campaign \#stayingalive (MSF 2016g) and \#notatarget (MSF 2016e).

As noted, a further distinctive feature of MSF work is that it does not participate in the UN cluster system. MSF objects to the emphasis on coordination as a humanitarian goal in itself. For MSF, coordination has to be "useful, guided by the reality of the situation on the ground and directed toward concrete action. The limits of the mechanisms of coordination must be recognised: faced with political interference in humanitarian aid, the solution resides not in multiplication or strengthening of technical measures, but rather in the need for humanitarian organisations and the international community to highlight political constraints and ascribe responsibilities" (Dubuet and Tronc 2006, 2).

MSF's views on the complex interaction between humanitarian action and politics are markedly different from the other three NGOs here studied. According to a former MSF head "humanitarian action is noble when coupled with political action and justice. Without them is doomed to failure" (Destexhe cited in Chandler 2002, 43). This vision was widely reflected in comments from MSF field staffers I interviewed at the time of the controversial EU-Turkey deal mentioned earlier. An MSF communications manager told me "this is a political crisis and has been created by the European Union and other member states. To respond to this crisis, we have to take a political stance." Another MSF interviewee explained that: "Sometimes, we would like to continue with public advocacy but because we are also carrying out private negotiations with the army and the government, it is better to not publicly speak out, because the medical needs are still there, and we need to address them as

\footnotetext{
${ }^{9}$ Interview with MSF Communication Manager, April, 25th 2017, Athens.
} 
soon as we will have the opportunity." 10 MSF has not hesitated to withdraw from operational engagement in the belief that it,could do more harm than good (Chandler 2002) or completely refused to intervene (Fassin 2007). Interestingly, when I directly asked a senior MSF manager about MSF's involvement in governance, I was told that "we do not participate in global governance. We have been very involved as a global health actor, when the other were not doing anything but we do not have a role in global governance." "11 For MSF' position toward politics, MSF has been considered as part of a 'Latin' tradition of humanitarianism that, in opposition to the Anglo-Saxon model, tends to have an antagonistic relationship with power (Tong 2004). Rieff has defined this approach as "disobedient humanitarianism" (Rieff 2003, 272).

\title{
4.5.2 MSF and Syrian Displacement
}

MSF has responded to the Syrian emergency in Bulgaria, France, Greece, Italy, Iraq, Jordan, Lebanon, Syria, Turkey and Tunisia. MSF's Syrian crisis response has focused exclusively on humanitarian assistance delivered on the basis of needs and has not included any form of development activity. Unlike other agencies investigated who declined to provide details of in-country operations citing security concerns. MSF has been quite vocal, declaring that:

\begin{abstract}
the Syrian government has not granted MSF authorisation to operate in the country, despite repeated requests, and insecurity has limited MSF's ability to provide assistance in opposition-controlled areas. Following the Islamic State (IS) group's abduction and release of MSF staff in 2014, and the impossibility of obtaining the necessary safety guarantees from its leadership, MSF withdrew from IS-controlled areas. In 2016, MSF continued to operate directly in six medical facilities in regions controlled by other opposition forces across northern Syria and provide distance support to Syrian medical networks in areas where MSF cannot be directly present. (MSF 2016d).
\end{abstract}

Inside Syria MSF has mainly focused on provision of medical supplies, basic health services and surgery, maternal health, vaccination campaigns, mental health and psychosocial support. In some areas it has also implemented water and sanitation programme and relief items distributions.

In refugee hosting states MSF has offered primary health care, psychosocial support, maternal healthcare, mental health, health promotion, and (in Jordan) medical evacuation of the wounded). In Tunisia, it has supported local organizations building the capacities of Tunisian and Libyan fishermen and coastguards in SAR and management of corpses. Along the migration route, MSF has provided mental health care in reception centres (in Italy), and medical care, shelter, relief items and hygiene kits at borders. In Greece, after the EU-Turkey deal left migrants stranded in Greece, the organization has provided lifesaving surgery and medical care to

\footnotetext{
${ }^{10}$ Interview with MSF Humanitarian Affairs Officer, May 17th 2017, Amman.

${ }^{11}$ Interview with MSF Director of Operational Support, April 25th 2017, Athens.
} 
people on the move.. In March 2016, MSF withdrew from the Moria detention facility on the Greek island of Lesbos, stating that it had become "a pre-removal detention centre, offering little guarantee of respect for human rights'(MSF 2016c).

With regards to the advocacy around Syrian displacement and Mediterranean migration, MSF has produced several reports, statements and press releases, severely rebuked governments and used social media to confront state policies. Overall, the NGO's communication appears quite different from the dominant Chouliaraki's post-humanitarian communication (Chouliaraki 2010) based on grand emotions and in search for (individual) emotive engagement with the humanitarian subject. MSF communication results more openly political both in the ways humanitarian crisis are presented to the public (for information and fundraising purposes), and for its often confrontational position toward governments' politics.

In relation to SAR operations which it began in $2015 \mathrm{MSF}$ has operated vessels crewed by MSF staff, and has provided medical personnel to other boats working to save lives at sea. Cuttitta has shown how MSF's SAR work has from the outset been presented as highly political, in contrast with the position taken by other NGOs supporting maritime SAR. For MSF, "humanitarian work can't be kept separated from the investigation and critique of the causes that make humanitarian work necessary" (Cuttitta 2017, 9). Beside the primary goal of saving lives, MSF has publicised its SAR engagement and visibility in order to present "a more humanized image of migration, one which is alternative to the stereotypical picture of an invasion caused by criminal actors, and, second, to ask for safe passages" (MSF representative quoted in Cuttitta 2017, 10).

\subsection{Conclusion}

This chapter has shown the role that each of the organizations wants to have in global governance and how they position themselves in terms of its relationship with politics. Table 4.1 schematically outlines the four organizations' self-perception regarding their role in global governance and relationship with politics.

Save the Children perceives and presents itself as a key player in global governance as confirmed by the organization's complete embrace of the main characteristics of the new humanitarianism (multi-mandate mission, rights-based and transformative approaches, strong focus on advocacy). In contradiction however, Save the Children 's self-perception and self-representation seems based on a clearly apolitical stance, compliant with humanitarian principles and international standards. It consistently presents activities for the promotion and protection of children's rights as technical and apolitical. However, analysis has shown that through psychosocial and SAR operations, the agencies contributes to the SCF has demonstrated the effects of pathologization and depoliticization of refugees, indicating the highly political role that Save the Children plays in refugee governance. 
Table 4.1 NGOs, global governance and politics

\section{NGOs, GLOBAL GOVERNANCE AND POLITICS}
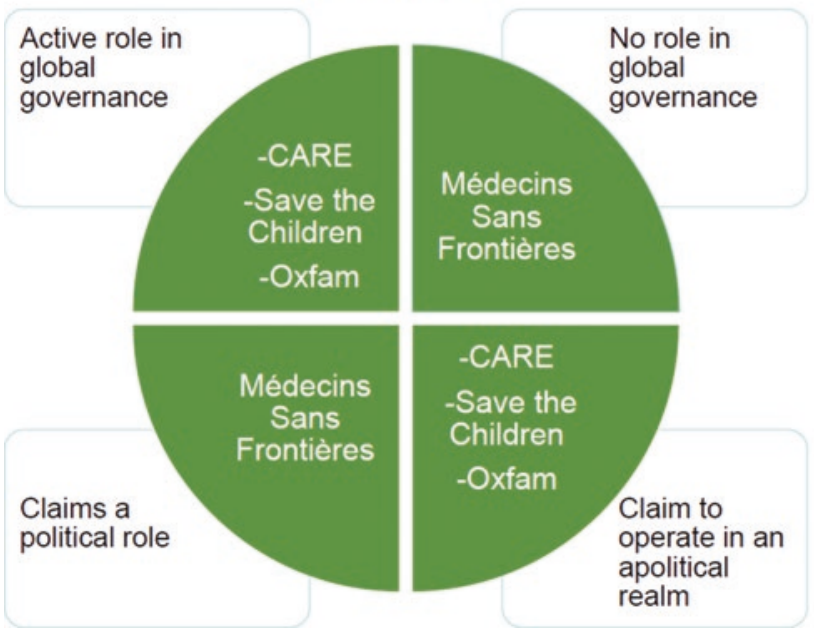

Oxfam shares with Save the Children a pre-occupation with forging a crucial role in global governance. It combines a strong relationship with governmental institutions with a more confrontational attitude toward state politics. Oxfam's focus on rights, people's voices and empowerment, as something neutral, unconnected from politics, is considered and presented as technical expertise, allowing Oxfam to avoid open reference to systems of power and politics. Despite the stress it puts on giving voice to beneficiaries, the analysis has shown how it consistently contributed to the depoliticization of the refugee issue.

CARE has also fully embraced and publicized the key role that it seeks to play in global governance and portrays itself as apolitical. Its gender transformative approach, through which the organization aims at redefining social relations and power dynamics, indicates its crucial ambiguity While urging a transformative approach it categorically denies any political will or political implications of its programs. CARE is aware of this tension and seeks to solve it by claiming to act only within the realm of human rights - which is considered by the organization as a neutral and technical space located outside the political sphere.

In complete contrast, MSF does not perceive and present itself as playing a role in global governance and has made its active engagement with politics a distinctive feature. MSF has vigorously insisted on its political (and financial) independence in order to be able to maintain space to maneuver and, when needed, to contest States. It has always considered politics an important aspect of its humanitarian intervention.

Overall, despite the four NGOs' different positions and self-representation regarding their role in global governance and relationship with politics, this chapter has shown how the work humanitarian agencies perform in the field is highly 
political and inevitably has a role both in humanitarian and wider global governance. Beyond each humanitarian NGO's self-positioning this study is interested in exploring specifically how their forms of visual representation contribute to shape the role that relief agencies perform in global, particularly refugee, governance. In the following chapters, the analysis will move to the investigation of the relief agencies visual communication to see how the visual practices of representation of the people they are assisting, especially Syrians on the move, relates with the roles transnational humanitarian NGOs want to have.

\section{References}

Abu-Lughod, L. (2002). Do Muslim women really need saving? Anthropological reflections on cultural relativism and its others. American Anthropologist, 104(3), 783-790.

Achilli, L.. (2016). Tariq Al-Euroba: Displacement trends of Syrian asylum seekers to the EU. 9290843721.

Barnett, M. (2009). Evolution without Progress? Humanitarianism in a World of Hurt. International Organization, 63(4), 621-663.

Barnett, M., \& Weiss, T. G. (2008). Humanitarianism in question: Politics, power, ethics. Ithaca: Cornell University Press.

CARE. (2012). Twitter CARE Syria response (@CARESyriaResp). Twitter 2012. https://twitter. com/CARESyriaResp

CARE. (2014). Working for poverty reduction and social justice: The CARE 2020 Program Strategy. http://insights.careinternational.org.uk/media/k2/attachments/CARE_2020_ Program_Strategy-English.pdf

CARE. (2016a). Care 2020 program strategy: Humanitarian response. https://www.care-international.org/files/files/Summary-Humanitarian\%20Response.pdf

CARE. (2016b). Facebook CARE Syria response. 2016. https://www.facebook.com/ CARESyriaResponse/

CARE. (2016c). What would you take: Syrian refugee crisis | CARE. 2016. https://web.archive. org/web/20160528135836/http://www.care.org/emergencies/syria-crisis/care-for-refugees/ what-would-you-take

CARE. (2017). Vision and mission | Care international. 2017. https://www.care-international.org/ who-we-are/vision-and-mission

CARE. (2018a). CARE's approach | Care international. 2018. https://www.care-international.org/ what-we-do/cares-approach

CARE. (2018b). Corporate partnerships. CARE. 2018. https://www.careinternational.org.uk/ get-involved/corporate-partnerships

Care International. (2016). Empowering women and girld affected by crisis.

Care International. (2017). Care international annual report FY16. https://www.care-international. org/files/files/publications/Care_International_Annual_Report_2017_8921_ENG_12_ Online(4).pdf

Chandler, D. (2001). The road to military humanitarianism: How the human rights NGOs shaped a new humanitarian agenda. Human Rights Quarterly, 23(3), 678-700.

Chandler, D. (2002). From Kosovo to Kabul: Human rights and international intervention. London: Pluto Press.

Chouliaraki, L. (2010). Post-humanitarianism: humanitarian communication beyond a politics of pity. International Journal of Cultural Studies, 13(2), 107-126.

Chouliaraki, L. (2012). The theatricality of humanitarianism: A critique of celebrity advocacy. Communication and Critical/Cultural Studies, 9(1), 1-21. 
CHS. (2020). Core humanitarian standard. 2020. https://corehumanitarianstandard.org/ the-standard

Cuttitta, P. (2017). Repoliticization through search and rescue? Humanitarian NGOs and migration management in the central mediterranean. Geopolitics, 1-29.

DuBois, M. (2007). Protection: The new humanitarian fig-leaf. Dialogues, 4, 1.

Dubuet, F., \& Tronc, E. (2006). United Nations: Deceptive humanitarian reforms? MSF international activity report 2006.

Duvall, S. (2009). Dying for our sins: Christian salvation rhetoric in celebrity colonialism. In R. Clarke (Ed.), Celebrity colonialism: Fame, power and representation in colonial and postcolonial cultures (pp. 91-106). Newcastle: Cambridge Scholars.

Fassin, D. (2007). Humanitarianism as a politics of life. Public Culture, 19(3), 499-520.

Grande, E. (2016). "I'm doing it for myself!": The aggressive promotion of the individual self as the dark side of women's rights. In A. De Lauri (Ed.), The politics of humanitarianims. Power, ideology and aid. London: I.B. Tauris.

Hillendrand, E., Karim, N., Mohanraj, P, \& Wu, D. (2015). Measuring gender-transformative change a review of literature and promising practices.

IFRC. (1994). Code of conduct for the international red cross and red crescent movement and NonGovernmental Organizations (N GO s) in disaster relief.

Kapoor, I. (2012). Celebrity humanitarianism: the ideology of global charity. Routledge.

Mahmood, S. (2011). Politics of piety: The islamic revival and the feminist subject. Princeton University Press.

MSF. (2016a). Access campaing. Médecins Sans Frontières Access Campaign, 2016. https:// msfaccess.org/.

MSF. (2016b). Access to medicines | MSF medical response. Médecins Sans Frontières (MSF) International. 2016. /access-medicines

MSF. (2016c). Greece. Médecins Sans Frontières (MSF) International. 2016. http://www.msf.org/ en/where-we-work/greece

MSF. (2016d). International activity report 2016. MSF - IAR. 2016. http://activityreport2016.msf. org/country/syria/

MSF. (2016e). MSF - Not a target. MSF - Not A Target I Médecins Sans Frontières. 2016. http:// notatarget.msf.org/

MSF. (2016f). Patent opposition database. Médecins Sans Frontières (MSF) International. 2016. https://www.msf.org/patent-opposition-database

MSF. (2016g). Stay alive. 2016. http://stayingalive.msf.org/

MSF. (2016h). MSF to no longer take funds from EU member states and institutions. 16 June 2016. https://www.msf.org.uk/article/msf-no-longer-take-funds-eu-member-states-and-institutions

MSF. (2017a). About MSF. Médecins Sans Frontières (MSF) International. 2017. http://www.msf. org/en/about-msf

MSF. (2017b). Who we are. Médecins Sans Frontières (MSF) International. 2017. https://www. msf.org/who-we-are

MSF. (2018a). About us. Médecins Sans Frontières (MSF) International. 2018. https://www. msf.org/

MSF. (2018b). Closing a Programme. Médecins Sans Frontières (MSF) International. 2018. http:// www.msf.org/en/closing-programme

MSF. (2018c). MSF history. Médecins Sans Frontières (MSF) International. 2018. http://www. $\mathrm{msf}$.org/en/msf-history

MSF. (2018d). Where we work. Médecins Sans Frontières (MSF) International. 2018. http://www. msf.org/en/where-we-work-0

NGOs Platforms et al. (2017). Stand and deliver. Urgent action needed on commitments made at the London conference one year on. https://www.savethechildren.net/sites/default/files/libraries/Stand\%20and\%20Deliver\%20digital.pdf

Oxfam. (2013). The power of people against poverty. Oxfam strategic plan, 2013 - 2019. https:// www.oxfam.org/sites/www.oxfam.org/files/oxfam-strategic-plan-2013-2019.pdf 
Oxfam. (2016a). Join Hands \#withSyria. Twitter. 2016. https://twitter.com/Oxfam/ status/709351389013663745

Oxfam. (2016b). Protect refugees and migrants. 2016. https://web.archive.org/ web/20180627065149/https://actions.oxfam.org/international/

Oxfam. (2016c) Syria refugee crisis: Is your country doing its fair share? Oxfam International. 2016. https://www.oxfam.org/en/syria-refugee-crisis-your-country-doing-its-fair-share

Oxfam. (2017a). Our purpose and beliefs I Oxfam International'. 2017. https://www.oxfam.org/en/ our-purpose-and-beliefs $\% 20$

Oxfam. (2017b). Oxfam annual report 2015-2016. https://www.oxfam.org/sites/www.oxfam.org/ files/file_attachments/oxfam_annual_report_2015_-_2016_english_final_0.pdf

Oxfam International. (2013). Oxfam's role in humanitarian action.

Oxfam International. (2018a). Crisis in Syria | Oxfam International. 2018. https://www.oxfam.org/ en/emergencies/crisis-syria

Oxfam International. (2018b). History of Oxfam international I Oxfam International. 2018. https:// www.oxfam.org/en/countries/history-oxfam-international

Oxfam International. (2018c). How we fight poverty I Oxfam International. 2018. https://www. oxfam.org/en/explore/how-oxfam-fights-poverty

Oxfam International. (2018d). Our work | Oxfam International. 2018. https://www.oxfam.org/en/ explore/issues-we-work-on

Pupavac, V. (2001a). Misanthropy without borders: The international children's rights regime. Disasters, 25(2), 95-112.

Pupavac, V. (2001b). Therapeutic governance: Psycho-social intervention and trauma risk management. Disasters, 25(4), 358-372.

Rajaram, P. K. (2002). Humanitarianism and representations of the refugee. Journal of Refugee Studies, 15(3), 247-264. https://doi.org/10.1093/jrs/15.3.247.

Rieff, D. (2003). A bed for the night: Humanitarianism in crisis. Simon and Schuster.

Save the Children. (2005). Child rights programming handbook. How to Apply Rights-Based Approaches to Programming. https://resourcecentre.savethechildren.net/node/2658/ pdf/2658.pdf

Save the Children. (2014). Most shocking second a day video. 2014. https://www.youtube.com/ watch? $\mathrm{v}=\mathrm{RBQ}-\mathrm{IoHfimQ}$

Save the Children. (2016a). Global corporate partnership brochure. https://www.savethechildren. net/sites/default/files/Global\%20Corporate\%20Partnership\%20Brochure.pdf

Save the Children. (2016b). Save the children annual report 2015. https://www.savethechildren. net/annualreview/ui/docs/Save_the_Children_Annual_Report_2016.pdf

Save the Children. (2016c). Save the Children's Global Strategy: Ambition for Children 2030 and 2016-2018 Strategic Plan. https://www.savethechildren.net/sites/default/files/Global\%20 Strategy\%20-\%20Ambition\%20for\%20Children\%202030.pdf

Save the Children. (2016d). Still the most shocking second a day. https://www.youtube.com/ watch? $\mathrm{v}=\mathrm{nKDgFCojiT} 8$

Save the Children. (2017). European refugee crisis. Programme and Advocacy Report. https:// www.savethechildren.net/sites/default/files/libraries/European\%20refugee\%20crisis_programme $\% 20$ and $\% 20$ advocacy\%20report_Feb\%202017.pdf

Save the Children. (2018a). Advocacy. Save the Children International. 2018. https://www.savethechildren.net/advocacy

Save the Children. (2018b). Child rights governance. Save the Children International 2018. https:// www.savethechildren.net/what-we-do/child-rights-governance

Save the Children. (2018c). Emergencies. 2018. https://www.savethechildren.org.uk/ how-you-can-help/emergencies

Save the Children. (2018d). Minori migranti: il lancio oggi della campagna social "The Space Migrant". Save the Children Italia. 2018. https://www.savethechildren.it/press/minorimigranti-il-lancio-oggi-della-campagna-social-\%E2\%80\%9C-space-migrant $\%$ E2\%80\%9D 
Save the Children. (2018e). Our humanitarian work. Save the Children International. 2018. https:// www.savethechildren.net/what-we-do/our-humanitarian-work

Save the Children. (2018f). Our vision, mission and values. Save the Children International. 2018. https://www.savethechildren.net/about-us/our-vision-mission-and-values

Save the Children. (2018g). Syria every last child. Every Last Child. 2018. https://campaigns. savethechildren.net/country/syria

Slim, H. (1997). Relief agencies and moral standing in war: Principles of humanity, neutrality, impartiality and solidarity. Development in Practice, 7(4), 342-352.

Sphere. (2020). What are humanitarian standards? I Sphere standards. Sphere. 2020. https:// spherestandards.org/humanitarian-standards/

Stoddard, A. (2003). Humanitarian NGOs: Challenges and trends. 12. Humanitarian Policy Group (HPG) Briefing. HPG.

'Syria Crisis: Dear World - We Are People'. 2016. CARE. 2016. https://www.careinternational. org.uk/stories/syria-crisis-dear-world-\%E2\%80\%93-we-are-people

Tong, J. (2004). Questionable accountability: MSF and sphere in 2003. Disasters, 28(2), 176-189.

UN Women. (2018). Gender equality glossary. https://trainingcentre.unwomen.org/mod/glossary/ view.php?id=36\&mode=letter\&hook=G\&sortkey=\&sortorder $=\&$ fullsearch $=0$ \&page $=-1$

Van den Bulck, H. (2009). The white woman's burden: Media framing of celebrity transnational adoptions. In R. Clarke (Ed.), Celebrity colonialism: Fame, power and representation in colonial and postcolonial cultures (pp. 123-140). Newcastle: Cambridge Scholars.

Various NGOs. 2015. Failing Syria. Assessing the impact of UNSCR in protecting and assisting civilians in Syria. https://www.savethechildren.net/sites/default/files/libraries/FailingSyria_ Report_March2015.pdf

Open Access This chapter is licensed under the terms of the Creative Commons Attribution 4.0 International License (http://creativecommons.org/licenses/by/4.0/), which permits use, sharing, adaptation, distribution and reproduction in any medium or format, as long as you give appropriate credit to the original author(s) and the source, provide a link to the Creative Commons license and indicate if changes were made.

The images or other third party material in this chapter are included in the chapter's Creative Commons license, unless indicated otherwise in a credit line to the material. If material is not included in the chapter's Creative Commons license and your intended use is not permitted by statutory regulation or exceeds the permitted use, you will need to obtain permission directly from the copyright holder.

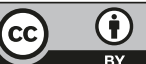

